\title{
An experiment on energy-saving competition with socially responsible consumers: opening the black box
}

Article

Accepted Version

Georgantzis, N. and Vasileiou, E. (2015) An experiment on energy-saving competition with socially responsible consumers: opening the black box. Journal of Behavioral and Experimental Economics, 58. pp. 1-10. ISSN 2214-8043 doi: https://doi.org/10.1016/j.socec.2015.06.002 Available at https://centaur.reading.ac.uk/40401/

It is advisable to refer to the publisher's version if you intend to cite from the work. See Guidance on citing.

To link to this article DOI: http://dx.doi.org/10.1016/j.socec.2015.06.002

Publisher: Elsevier

All outputs in CentAUR are protected by Intellectual Property Rights law, including copyright law. Copyright and IPR is retained by the creators or other copyright holders. Terms and conditions for use of this material are defined in the End User Agreement.

www.reading.ac.uk/centaur 
Central Archive at the University of Reading

Reading's research outputs online 


\title{
AN EXPERIMENT ON ENERGY-SAVING COMPETITION WITH SOCIALLY RESPONSIBLE CONSUMERS: OPENING THE BLACK BOX*
}

\author{
Efi Vasileiou ${ }^{1}$ \\ Nikolaos Georgantzís ${ }^{2}$
}

\begin{abstract}
We present results from experimental price-setting oligopolies in which green firms undertake different levels of energy-saving investments motivated by public subsidies and demand-side advantages. We find that consumers reveal higher willingness to pay for greener sellers' products. This observation in conjunction to the fact that greener sellers set higher prices is compatible with the use and interpretation of energy-saving behaviour as a differentiation strategy. However, sellers do not exploit the resulting advantage through sufficiently high price-cost margins, because they seem trapped into "run to stay still" competition. Regarding the use of public subsidies to energy-saving sellers we uncover an undesirable crowding-out effect of consumers' intrinsic tendency to support green manufacturers. Namely, consumers may be less willing to support a green seller whose energysaving strategy yields a direct financial benefit. Finally, we disentangle two alternative motivations for consumer's attractions to pro-social firms; first, the self-interested recognition of the firm's contribution to the public and private welfare and, second, the need to compensate a firm for the cost entailed in each pro-social action. Our results show the prevalence of the former over the latter.
\end{abstract}

Keywords: corporate social responsability, energy savings, public good, oligopoly experiments, vertical differentiation, altruism, environmental certification.

JEL Classification: C91, L11

\footnotetext{
* Financial support by the Spanish Ministry of Science and Innovation, project ECO 2011-23634, is gratefully acknowledged. Comments by an anonymous reviewer have helped us to substantially improve this manuscript.

1 International Faculty of the University of Sheffield, City College \& Laboratorio de Economía Experimental, Castellón, Spain, vasileiou.efi@gmail.com.

2 Agriculture Policy and Development, University of Reading, UK, n.georgantzis@reading.ac.uk.
} 


\section{Introduction}

Apart from purely altruistic motivation stemming from a manager's environmental concerns, firms undertake energy-saving investments as part of their corporate social responsibility (CSR) strategies pursuing specific economic benefits. ${ }^{3}$ Such benefits may result from a decrease in a firm's variable costs, access to public subsidies towards energy-saving production and demand-side advantages due to the firm's improved image among socially-responsible consumers. ${ }^{4}$ While the above has been noticed by different strands in the literature, the interplay between these effects has not been studied so far, mostly due to the difficulty in isolating them from a plethora of other coexisting factors and phenomena entailed both in the firms' market and non-market strategies and in the consumers' underlying motivations.

Several theoretical and empirical studies reviewed below accept that consumers tend to support sellers with some prosocial activity and that this motivates firms to make socially beneficial investments in an effort to differentiate themselves from other sellers. However, no motivation has been clearly identified as to why consumers would be willing to pay more for products sold by socially responsible firms. For example, it has not been clarified whether a consumer supports a prosocial seller because he appreciates the costs incurred during the prosocial activity, or because the activity itself has a direct utility-increasing effect for the consumer. Another policy-relevant question that has been left unanswered is whether a favorable public attitude towards energy-saving strategies through, say, a green supply chain subsidy, could have a crowding-out effect, going against the consumer's appreciation of a seller's CSR. In fact, it is commonly accepted that subsidizing green firms and increasing the consumers' awareness towards environmental issues can both be monotonically beneficial for the society and profitable for green producers. ${ }^{5}$ The effect that

\footnotetext{
${ }^{3}$ Milton Friedman (1970) argued that the responsibility of a corporate executive is to make as much money as possible, conforming to basic rules according to the law and ethical custom. This critical position towards CSR is also apparent in neoclassical economists' recent statements. See, for example, Henderson (2001), Jensen (2002) and Sundaram and Inkpen (2004). Other economists argue that within a context of globalization, nation states and their agencies are severely constrained in their ability to monitor and protect the rights of their citizens and to provide sufficient public goods. See, for example, Beck (2000), Kaul et al. (2003) and Scherer et al. (2007).

${ }^{4}$ Consistent with economic theories of the firm, McWilliams and Siegel (2001) suggest that the economic case is not to accept or reject CSR entirely, but to find an optimum level of CSR. Husted and Salazar (2006) extend these arguments to say that a strategic approach to CSR may help business firms to improve profitability and enhance social performance at the same time. They describe the context in which it may be possible to maximize social profit so that both society and business firms benefit. Distinguishing among strategic CSR, altruistic CSR, and even coerced CSR, McWilliams, Siegel, and Wright (2006) describe a variety of perspectives on CSR, which they use to develop a framework for consideration of the strategic implications of CSR. Baron (2001) defines strategic CSR as the use of CSR to attract socially responsible consumers, in the sense that firms provide a public good in conjunction with their marketing/business strategy.

${ }^{5}$ Endres (1997) proposes the use of state campaigns aimed at awakening people's ecological awareness. However, there are only a few studies focusing on the negative effects that such campaigns may have on the economic and environmental performance of product markets. For example García-Gallego \& Georgantzís $(2009,2011)$ argue that the state cannot rely upon private campaigns aiming at increasing the consumer's ecological awareness, because firms would benefit from increasing consumer heterogeneity by funding campaigns targeting the most
} 
a subsidy may have on a socially responsible consumer's attitude towards green firms has never been addressed so far.

Focusing on the interpretation of CSR as a product differentiation strategy, we can divide the relevant literature into three different groups. The first group considers ethical consumption as a source of vertical ${ }^{6}$ product differentiation assuming that all the consumers prefer buying the product with a CSR characteristic than the product without such a characteristic, although they have different valuations for it. The second group assumes horizontal ${ }^{7}$ product differentiation with some of the consumers' ideal varieties being closer to one product than another. The third group ${ }^{8}$ is a mix of the two former groups, assuming that consumers' population is split into two different exogenously given groups of consumers with different preferences: the group of convinced standard consumers and the group of potentially ethical consumers. Our framework relates to the first group in which product variants differ in their quality and consumers differ in their willingness to pay for quality, following the pioneering work of Mussa and Rosen (1978), Gabszewicz and Thisse (1979), and Shaked and Sutton ${ }^{9}(1982,1983)$.

Regarding the profitability of CSR, Reinhardt (1998) finds that a firm engaging in such a strategy can only generate an abnormal return if it can prevent imitation by its competitors. In competitive markets this is unlikely, since CSR is highly transparent. Other theoretical studies (Dutta et al., 1995; Hoppe and Lehmann-Grube, 2001) show that any early mover advantages that might be gained by offering higher quality products are eroded when competitive strategies are observable. Our work relates with research on CSR in oligopoly theory and public economics. While some models predict that firms producing a higher quality product earn 'abnormal' returns, these findings hinge on the assumption that costs are constant and independent of quality. ${ }^{10}$ However, in the case of energysaving investments, it is usually the case that they tend to increase a firm's fixed costs, while decreasing variable costs. Furthermore, some economic models of CSR (Baron, 2001; Fedderson and Gilligan, 2001) identify an important countervailing force on the ability of companies to engage in strategic CSR in oligopolistic industries: activists who target leading firms. This countervailing force makes it difficult for oligopolistic firms to achieve a competitive advantage through the strategic use of CSR. Another related strand in the literature considers CSR as a private contribution to a public

environmentally conscious of the consumers. On the contrary, they show that state campaigns should aim at increasing the ecological awareness of the least environmentally conscious consumers.

${ }^{6}$ See Amacher et al. (2004), Uchida (2007), Calveras et al. (2007), Mitrokostas and Petrakis (2008), Baron (2009), Bottega and De Freitas (2009), Casadesus-Masanell et al (2009), Toolsema (2009) and García-Gallego and Georgantzís (2009).

${ }^{7}$ See Solferino and Becchetti (2008) and Conrad (2005).

${ }^{8}$ See Davies (2005) where the size of groups of consumers is exogenously given and Fanelli (2008) where is not.

${ }^{9}$ Arora and Gangopadhyay (1995) apply this model to voluntary overcompliance of firms with established government standards. In their model the market gets segmented by income levels and firms with different levels of environmental-friendliness are able to charge different prices and achieve a positive profit. Choi and Shin (1992) modify the vertical differentiation model by Shaked and Sutton (1982) allowing for an uncovered market based on "taste diversity".

${ }^{10}$ In fact, most theoretical models focus on quality-related increases in either fixed or variable production costs. For example, see Crampes and Hollander (1995) and Lutz et al. (2000). 
good. ${ }^{11}$ Bagnoli and Watts (2003) study the feasibility of CSR by private firms with "warm-glow" (in Andreoni's $(1989,1990)$ sense) preferences for public goods. They conclude that, when firms explicitly link provision of a public good to sales of the private good they offer, the provision of the public good is inversely related to the competitiveness of the market. Specifically related to our framework, they find that if provision of the public good is not explicitly linked to the sales of the private good and there is free entry, too little of the public good is privately provided. ${ }^{12}$

Our paper relates to three experimental papers. First, Cason and Gangadharan (2002) study sellers' incentives to offer products of differing environmental quality. The authors conclude that the regulator can improve environmental performance by providing the option of certified green labeling in a posted offer market with 5 sellers and 6 buyers that lasts for 20 periods. When offered the possibility of selling products certified by a third party at a fixed cost, unknown to buyers, most sellers pay for the certification and endogenously decide to deliver environmentally friendly products, while cheap talk or reputation building are ineffective in increasing market efficiency significantly. A key difference with our framework is that the environmentally superior product has a higher unit cost and benefits only the buyer of that product whereas we consider that every consumer, whether buying or not the ecological varieties, benefits from all producers' investment in cleaner production. Second, Rode et al (2008) study ethical differentiation of products in triopolistic experimental markets where producers set prices for the exogenously determined varieties they sell. The high quality producer's costs were higher than the others. In two treatments, the additional costs were attributed to compliance with ethical guidelines. In the third, no justification was provided. Many consumers reduced their experimental gains by purchasing the ethically differentiated products at higher prices. The extra cost of producing a superior unit was effectively donated to an NGO fighting child labor, having thus a potentially different valuation for every experiment participant, while in our framework the contribution to the social fund is equally shared among all consumers. We revisit the experimental data-set of Barreda et al. (2011), who investigate whether firms' concerns for socially beneficial

\footnotetext{
${ }^{11}$ Kotchen (2006) develops a general model of private provision of a public good that includes the option to consume an impure public good. This article shows that, if a green market is not sufficiently large or environmental quality is not a gross complement for private consumption, introducing a green market may actually discourage private provision of an environmental public good and diminish social welfare. Besley and Ghatak (2007) find that firms that use CSR will produce public goods at exactly the same level as predicted by the standard voluntary contribution equilibrium for public goods, hence always leads to an excessive level of public goods. Baron (2007) considers the formation of firms that can engage in costly CSR and shows that shareholders rather than social entrepreneurs bear the cost, unless the CSR is a surprise. A social entrepreneur is willing to bear the cost either because doing so expands the opportunity sets of citizens in consumption-social giving space or because there is an entrepreneurial warm-glow from the firm's social responsibility. A social entrepreneur carries strategic CSR beyond profit and market value maximization. Baron (2008) presents a theory of CSR in the form of the private provision of public goods and private redistribution by a firm. In this article the firm privately provides the public good in response to the preferences of its consumers, shareholders, and managers, and if shareholders had altruistic preferences for the beneficiaries of the social expenditures more would be provided subject to any crowding out by government expenditures. In a more recent article Baron (2009) considers motivation underlying CSR in a setting in which firms compete directly in a market.

${ }^{12}$ Firms enter until profits are zero, thus, they can only capture the participation benefits that accrue to consumers but not the common benefits of having a positive quantity of the public good available.
} 
objectives is the result of strictly economic motivation or, alternatively, whether the non selfish hypothesis survives after strictly economic motivations have been accounted for. They find that, even when firms use altruistic donations as a profit oriented differentiation strategy, some of their investment is not recovered from their market activities maintaining at least a part of their pro-social behavior within the purely altruistic domain.

\section{Experimental Design}

In our design, nine sessions were conducted, with a total of 324 participants. Experimental subjects were students at the University Jaume I, Spain. Using standard procedures, subjects were recruited among voluntary undergraduate students from different economics and business-related courses. Before the session started, subjects were randomly distributed into two separate rooms, one for consumer-subjects and one for firm-subjects. Inside each room, an experimentalist gave each subject an identification number, read the corresponding written instructions and answered any remaining questions. $^{13}$

At the end of each session, subjects were privately paid in cash. Sessions lasted 150 minutes approximately. ${ }^{14}$ Average consumer-subject earnings were $30 €$, whereas firm-subjects earned on average slightly below $15 €$. In fact, following the results of pilot sessions, to compensate for possible losses, each firm-subject received an extra endowment of $15 €$. In the instructions, experimental earnings were expressed in ExCUs (experimental currency units) which were used to reward subjects at an exchange rate of $1 €=420$ ExCUs. Specific software, based on PHP programming, was created for this experiment. All sessions were carried out at the Laboratorio d'Economia Experimental in Castellón, Spain (LEE, http://www.lee.uji.es/).

Five treatments were designed, denoted as T0, T1, T2, T3 and T4. The main characteristics of each treatment are described in Table 1. Each market consists of 9 firms and 9 consumers. Firms produce a homogeneous commodity at a constant unit cost equal to 100 ExCUs (Experimental Currency Units). To avoid any end-game behaviour, subjects were informed that each market would last for at least 36 periods, after which a random ending rule would be activated. Therefore, some markets last substantially longer than others. Our discussion and results are based on the first 36 periods of each session, although graphs include all periods played. Each period, the consumer must purchase a unit of the good and has to decide which company to buy from. By design, no posted price can exceed the consumer's reservation price, so that not buying the good at all is ruled out. To buy the product, each period the consumer starts with an initial endowment of 200 ExCUs.

[Table 1 here]

In the baseline treatment $\mathrm{T} 0$, each period, firms simultaneously decide the selling price for the product. Once the 9 firms have made their price decisions, this information appears simultaneously on

\footnotetext{
${ }^{13}$ Instructions available upon request from the authors.

${ }^{14}$ Sessions in T0 lasted around 90 minutes.
} 
the computer screens of all consumers in the market. As long as prices are above the unit cost of 100 ExCUs, firms operate at a nonnegative profit. Consumers then must decide from which company to buy (the unit of) product. After the consumers' decisions, a new period starts in which each firm receives previous period information concerning prices charged by all firms in the market, the demand for each firm, and the per period and cumulative profits. As the session goes on, this information is stored in a complete history table available to all firm-subjects. Similarly, each consumer has a complete history table on the purchase prices he paid in each period, the number of the firm he bought the good from, and per period as well as accumulated own earnings.

In treatments $\mathrm{T} 1$ to $\mathrm{T} 4$, in addition to price, firm-subjects have to choose from a menu their energy-saving investment which is implemented to monotonically relate with different contribution levels to a public fund, shared equally among all consumers in the market at the end of each period. The menu offers 5 possible levels of investment in the public good, numbered 0 through 4 , so that level 0 means no contribution, and level 4 involves maximum contribution to the public good. For firms, a higher level of contribution in a given period involves a higher fixed cost, higher levels of energy efficiency, reducing the firm's cost, and a green subsidy which varies depending on the firm's investment level and on the specific scenario and treatment. Therefore, the net (fixed) cost for a contributing firm is its investment minus the cost saving, minus the subsidy received from the government. In T1, a low net contribution cost is implemented, whereas T2-T4 correspond to the high net cost condition. Apart from the basic scenario (S1), in each treatment we test another 4 scenarios (S2-S5) which appear on random periods of the session to elicit, in an incentive-compatible way, subjects' behaviour under different subsidy schemes. A detailed description of the subsidy scenarios implemented are provided in Tables 2 and 3. Given this endogenous fixed cost, selling above the unit production cost of 100 ExCUs does not guarantee positive profits. To avoid negative earnings, firmsubjects received an additional endowment of $15 €$ each. For consumers, in a market in which firms contribute to the public good, a higher level of total investment implies higher earnings due to the public fund, independently of how many consumers purchase from a specific contributing firm.

\section{[Table 2 here]}

\section{[Table 3 here]}

The time structure of the experiment for treatments T1-T4 is as follows. Firms play a three stage game. In the first stage, firms choose their investment which determines their contribution to the public good. In the second stage, they set prices. In the third stage, each consumer chooses from which firm to buy a unit of the product. Not purchasing the product at all is ruled out by design and by instruction, as posted prices are always lower than reservation prices. While price decisions take place in all periods, the level of investment is a long-term strategy, reflected on the fact that they decide on investment levels only in periods $1,7,13,19,25$, and 31 . This feature in our design represents the fact that, in the real world, pricing decisions can be changed more frequently than investments. Once all 
firms have made their decisions, each consumer receives information on the price and the investment level chosen by each firm. With this information, consumers decide from which firm to purchase the product. Following this decision and the feedback received by the subjects, a new period starts. In T1 and T2, each firm only has information concerning the transactions made in the previous period. This corresponds to the "No history" condition on Table 1. In T3, corresponding to the "Partial history"

condition on Table 1, firms have information on prices, demand and firm profits (but not investment levels) for all past periods. In T4, corresponding to the "Complete history" condition, the aforementioned history table is enhanced including investment levels in all past periods by all firms.

A comparison between $\mathrm{T} 1$ and $\mathrm{T} 2$ allows us to analyze how firms respond to quantitative changes associated with the relationship between private costs and social benefits. Moreover, comparing $\mathrm{T} 2$ and $\mathrm{T} 3$ allows us to analyze how firms respond to qualitative changes in the historical information on prices. Finally, the comparison between T3 and T4 makes possible to study how firms respond to qualitative changes in the historical information about investments.

\section{Firm behavior}

Figure 1 shows that, in the baseline Bertrand markets, prices have remained relatively close to the competitive level, 100, while, at the same time, a significant amount of heterogeneity is observed, both in the absence (markets 1 and 2) and in the presence of contribution strategies (markets 3-18). In fact, as can be seen from posted prices, in several markets, there have been systematic efforts to maintain higher than competitive prices, especially in the presence of an energy-saving strategy available to the firms. On the contrary, some markets have remained almost perfectly competitive, including cases of markets with an energy-saving strategy available to the firms, like for example market 13. Clearing prices (those at which consumers actually buy the product) have presented far less heterogeneous patterns, remaining much closer to the competitive level of 100 monetary units. This is more clearly reflected on average market clearing prices aggregated by treatment, presented in Figure 2. Generally speaking, we observe tight convergence of clearing prices to the competitive level in all treatments implemented.

\section{[Figure 1 here]}

[Figure 2 here]

However, when we take all periods into account, we find that the aforementioned pictures of convergence to the perfectly competitive price should not be mistakenly interpreted to imply that the availability of energy saving to firms leaves posted and clearing prices unaffected. On the contrary, when comparing prices obtained in the baseline treatment, T0 with those obtained in the other treatments $(\mathrm{T} 1-\mathrm{T} 4)$, we find that both posted $(\mathrm{M}-\mathrm{W}$ test, $\mathrm{p}=0.0014)$ and clearing prices $(\mathrm{M}-\mathrm{W}$ test, $\mathrm{p}=$ 0.0000) are significantly higher in the presence of CSR strategies, rather than in the absence of them. Therefore we can formally state the first result of our experiments: 


\section{RESULT 1: The adoption of energy-saving investments leads to higher posted and market clearing prices than in the absence of such strategies.}

Next, we refer to Figure 3. Observing the evolution of firms' energy-saving investments, we note a striking similarity to the usual temporal pattern of contributions obtained in standard public good experimental games. Specifically, contributions start relatively low and they rise during the early periods of the session, while they decrease over the remaining periods of the session. From Figure 4, we see that, analogously to clearing prices, which have been lower than posted ones, selling firms' ("clearing") contributions have been systematically higher than posted ones. Therefore, consumers have systematically preferred cheaper sellers and sellers who have contributed more to the public fund. However, this result is formally established and further refined in the analysis of the demand side behaviour, presented in the next section.

\section{[Figure 3 here] \\ [Figure 4 here]}

Figures 5 and 6 represent pricing (dots) and purchasing (marked with an " $x ")$ decisions on a bi-dimensional price-energy-saving space. Overall, we see that persistent dispersion exists in both sellers' and consumers' strategies. Firms tend to invest positive amounts to the greening of their production, posting at the same time higher than competitive prices. Towards the end of the experiment (especially, period 36), firms tend to set close to competitive prices, even when they have invested maximal amounts to energy saving processes. Consumers also tend to become more homogeneous in their behavior, choosing sellers who are investing more. In few words, sellers seem to recognize their ability to sustain higher prices in the short run by commiting to a greener behavior in the long run, in an effort to differentiate from other sellers. However, thanks to fierce competition among sellers, consumers tend to increasingly enjoy firms' altruism at lower and lower prices.

[Figure 5 here]

[Figure 6 here]

This pattern is now presented in a more formal way. First, we analyze firm $i$ 's pricing decision (logarithm of $p_{i}$ ) in period $t$ as a function of other firms' $(j)$ logarithm of average price in the previous period, $t-1$, as well as own and rival average contributions $\left(C_{i}, C_{j}\right.$, respectively) through the estimation of the following model:

$$
l p_{i t}=\alpha+\delta \cdot t+\beta_{0} \cdot l p_{i t-1}+\beta_{1} \cdot l p_{j t-1}+\sum_{k=1}^{4} \gamma_{k} \cdot C_{i t} \cdot \text { Treat }_{k}+\sum_{k=1}^{4} \mu_{k} \cdot C_{j t} \text { Treat }_{k}+u_{i t}
$$

where Treat $_{k}, k \in\{1,2,3,4\}$, is a treatment specific dummy. The estimates are presented in Table 4 . 
[Table 4 here]

The results of this estimation indicate the existence of several interesting patterns. Specifically, a firm reacts by raising its price as a response to its rival's higher prices in the previous period. The firm sets a higher price, the higher is its contribution to the public fund and the lower is its rival's contributions. Thus, a firm's price is higher, if it perceives its situation as advantageous in the energy-saving market, either through a higher own or a lower rival contribution. Furthermore, the firm is more likely to have a higher price, if the firm or its rivals had set a high price in the previous period. Finally, the only case in which rival contributions are insignificant in a firm's pricing decision is in T3. To understand this, recall that in Treatment 3 firms focus too much on other firms' prices (this is the only available information on opponents' behavior) and competition over contributions loses ground to price competition.

RESULT 2: Firms adopting higher energy-saving investments tend to set higher prices, whereas they set lower prices when their rivals adopt higher energy-saving investments. Prices of competitors behave like in standard differentiated oligopoly models, exhibiting strategic complementarities.

Thus, in this setup, adopting an energy-saving investment is like investing in higher product quality. It raises a firm's own price and decreases the rivals' prices, whereas prices exhibit the standard strategic complementarity pattern.

The most interesting pattern obtained on firm behavior is reported on Figure 7. While the baseline treatment has yielded the perfectly competitive outcome, driving firms' profits down to zero, markets with energy saving investments have been clearly unprofitable. We have also formally compared profits in T0 to profits in treatments T1-T4 and found that, in the latter, firms have earned significantly lower profits (M-W test, $\mathrm{p}=0.000$ ). We formally state next this finding:

RESULT 3: When firms adopt energy-saving investments, their gains from relaxing price competition do not compensate their increased costs.

[Figure 7 here]

In the following section we focus on the main findings of this experiment on consumer behaviour.

\section{Consumer behavior}

We report the results obtained on demand-side behavior relying on regression techniques and taking advantage of the panel data structure of our sample. Our basic specification is as follows: 
(2) $D_{i t}=X_{i t} \beta+\eta_{i}+\varepsilon_{i t}$

The demand variable $D_{i t}$ is an ordered categorical variable taking the value from 1 to 9 , therefore we employ a Random Effects Ordered Probit model where $i$ is the individual firm, $t$ is the period of observation, $\eta_{i}$ are the individual effects, $\varepsilon_{i t}$ is the error term. $X_{i t}$ includes the following variables: $:^{15}$ the firm's own price, the average of other's prices in the same period, the firm's own contribution, the other firms' average contribution, the subsidy when certificate from 1 to 4 is chosen by the firm (in model 1) or alternatively the saving costs (in model 2).

\section{[Table 5 here]}

We recognize the possibility that individual random effects, $\eta_{i}$, are likely to be correlated with some, if not all the explanatory variables. Suppose that the correlation takes place only through the long run components of the $X_{i t}$ variables and that these can be captured via the average, $\bar{X}_{i t}$, of these variables over time. ${ }^{16}$ This specification is only applied to firm's own price (the average of other's price) and firm's own contribution (the other firms' average contribution).

Table 6 reports the results obtained from the estimation of the demand model. We compare two alternative motivations for consumer's attraction to pro-social firms. Model 1 presents the estimation results of the demand model after controlling for the effect of the consumer self-interested recognition of the firm's contribution to the public and private welfare. Model 2 shows the estimation results of the demand model which incorporate the firms' cost entailed in each pro-social action.

[Table 6 here]

In line with the literature, our results confirm consumer's preferences for socially responsible firms: a firm's investment in energy saving has a positive effect on its own demand and a negative effect on the demand of its rivals, whereas prices have, as would be expected, exactly the opposite effects.

RESULT 4: Consumers react to energy-saving investments as if these were quality improvements in a firm's product. Prices have the expected effect on own and rival demand.

Comparing model 1 and 2, it is found that the main reason of consumers' willingness to support socially responsible firms, is that the activity itself has a direct utility-increasing effect, rather than the alternative of the consumer's willingness to compensate the firm's costs incurred during the pro-social activity.

\footnotetext{
${ }^{15}$ The variables included in the model are defined in Table 5.

16 This specification is based on Mundlak (1978) methodology by specifying the correlation between the individual random effects and the time-varying observables as a linear function of those observables.
} 
RESULT 5: Consumers prefer energy-saving manufacturers due to the effect of energy saving on the environment, rather than as a way of compensating them for the extra costs incurred.

Finally, as stated earlier, the actions of policy makers towards socially responsible firms and their impact on consumers' and firms' strategies must account for possible crowding-out effects. The working hypothesis here is that institutional support towards energy saving may affect consumers' responses towards socially responsible firms and, eventually, the socially responsible strategies of the latter. In our context, a subsidy may first, crowd out intrinsic genuinely altruistic motivations in firms' socially responsible action. This would correspond to the well-known first-order crowding out effect. We also uncover a second-order crowding out effect originating from consumers' reduced support for firms whose pro-social behavior is motivated by extrinsic compensations and subsidies. This undesirable effect of public incentives to pro-social behavior is especially relevant in lower levels of contribution to the public good. These findings indicate that the correct domain for measures supporting a corporation's socially responsible activities should be education and advertising aimed at increasing the consumer's or, directly, the entrepreneur's social consciousness, rather than subsidies.

RESULT 6: Subsidies to energy-saving producers may have a crowding-out effect, reducing the consumer's intrinsic willingness to support a firm's corporate social responsibility.

\section{Conclusions}

The true motivation of firms and consumers in the presence of energy-saving competition is difficult to study in isolation from other motivations and phenomena occurring in the real world. Thus, real world data have hardly given us reliable information on socially responsible consumers' motivations and on the role and weight of these motivations on firms' strategy saving decisions. Furthermore, public policies towards energy-efficient firms may interact with consumers' motivation and yield unexpected effects on the market outcome. We have used data from the lab to address these and other questions.

Our findings confirm that energy-saving investments have similar effects to those of vertical product differentiation. Firms adopting higher energy-saving investments behave as if they were selling a superior product, allowing them to set higher prices. However, they end up competing too much among them, lowering their prices close to competitive levels. Thus, they do not recover their energy-saving costs and incur losses. This turns their ex ante profit-driven strategy into an ex post purely altruistic contribution to the public good.

Consequently, consumers deal with energy-saving firms' products as if they were the result of costly quality improvements. Regarding consumer behaviour, we are the first to show that consumers exhibit a higher willingness to pay for energy-saving firms' products due to the positive externality 
this has on the environment, rather than as a way of compensating firms for the extra costs they incur. We are also the first to show that public subsidies to energy-saving firms may have an undesirable crowding-out effect, as they reduce the consumer's intrinsic willingness to support energy-saving manufacturers.

Both results have critical implications for economic policy in product markets with energyintensive production processes, as they suggest that consumers may not appreciate firms' investment as a cost to the seller but as a benefit to the society as a whole. Finally, subsidies could overlap in an undesirable way with intrinsic motivations, failing to achieve the pretended efficiency-inducing outcomes. 


\section{References}

Amacher, G., Koskela, E. and M. Ollikainen, 2004, Environmental quality competition and eco-labeling, Journal of Environmental Economics and Management 47, 284-306.

Andreoni, J., 1989, Giving with Impure Altruism: Applications to Charity and Ricardian Equivalence, Journal of Political Economy 97, 1447-1458.

Andreoni, J., 1990, Impure Altruism and Donations to Public Goods: A Theory of WarmGlow Giving, Economic Journal 100, 464-477.

Arora, S. and S. Gangopadhyay, 1995, Toward a Theoretical Model of Voluntary Overcompliance, Journal of Economic Behavior and Organization 28, 289-309.

Bagnoli, M. and S. Watts, 2003, Selling to Socially Responsible Consumers: Competition and the Private Provision of Public Goods, Journal of Economics and Management Strategy 12, 419-445.

Baron, D., 2001, Private Politics, Corporate Social Responsibility and Integrated Strategy, Journal of Economics and Management Strategy, 10, 7-45.

Baron, D., 2007, Corporate Social Responsibility and Social Entrepreneurship, Journal of Economics and Management Strategy 16, 683-717.

Baron, D., 2008, Managerial Contracting and Corporate Social Responsibility, Journal of Public Economics 92, 268-288.

Baron, D., 2009, A Positive Theory of Moral Management, Social Pressure, and Corporate Social Performance, Journal of Economics and Management Strategy 18, 7-43.

Barreda, I., García-Gallego, A., Georgantzís, N., Jaramillo-Gutiérrez, A., and G. SabaterGrande, 2011, An Experiment on the Motivation and the Effects of Socially Responsible Market Behavior, International Journal of Ecological Economics and Statistics 23, 105-128.

Beck, U., 2000, What is Globalization? Cambridge, UK: Polity Press.

Besley, T. and Ghatak, M., 2007, Retailing public goods: the economics of corporate social responsibility. Journal of Public Economics 91, 1645-1663.

Bottega, L. and De Freitas, J., 2009, Public, Private and Nonprofit Regulation for Environmental Quality, Journal of Economics and Management Strategy 18, 105-123.

Calveras, A., J.J. Ganuza and L. Llobet, 2007, Regulation, Corporate Social Responsibility and Activism, Journal of Economics and Management Strategy 16, 719-740.

Casadesus-Masanell, R. Crooke, M., Reinhardt, F. and Vasishth, V., 2009, Households' Willingness to Pay for "Green" Goods: Evidence from Patagonia's Introduction of Organic Cotton Sportswear, Journal of Economics and Management Strategy 18, 203-233.

Cason T.N. and Gangadharan L., 2002, Environmental labeling and incomplete consumer information in laboratory markets, Journal of Environmental Economics and Management 43, 113134. 
Choi, C.J. and H.S. Shin, 1992, A Comment on a Model of Vertical Product Differentiation, Journal of Industrial Economics 40, 229-232.

Conrad, K., 2005, Price Competition and Product Differentiation when Consumers Care for the Environment, Environmental and Resource Economics 31, 1-19.

Crampes, C and Hollander, A., 1995, Duopoly and Quality Standards, European Economic Review 39, 71-82.

Davies B. R., 2005, Abstinence from child labor and profit seeking, Journal of Development Economics 76: 251-263.

Dutta, P. K., Lach, S. and Rustichini, A., 1995, Better late than early: vertical differentiation in the adoption of a new technology, Journal of Economics and Management Strategy 4, 563-89.

Fanelli, D., 2008, A Two-Stage Duopoly Game with Ethical Labeling and Price Competition when Consumers differ in Preferences MPRA Paper No. 11544.

Feddersen, T. and T. Gilligan, 2001, Saints and Markets: Activists and the Supply of Credence Goods, Journal of Economics and Management Strategy 10, 149-171.

Friedman, M., 1970, The Social Responsibility of Business Is to Increase Its Profits, The New York Times Magazine (13 September) 32-33, 122, 126.

Gabszewicz, J.J., and Thisse, J-F., 1979, Price competition, quality and income disparities, Journal of Economic Theory 20, 340-359.

García-Gallego, A. and Georgantzís, N., 2009, Market Effects of Changes in Consumers' Social Responsibility, Journal of Economics and Management Strategy 18, 235-262.

García-Gallego, A. and Georgantzís, N., 2011, Good and Bad Increases in Ecological Awareness, Strategic Behavior and the Environment, 1, 71-88.

Henderson, P. D., 2001, Misguided Virtue. False Notions of Corporate Social Responsibility, London: Institute of Economic Affairs.

Hoppe, H. and Lehmann-Grube, U., 2001, Second-mover advantages in dynamic quality competition, Journal of Economics and Management Strategy 10, 419-33.

Husted, B. W. and De Jesus Salazar, J., 2006, Taking Friedman seriously: maximizing profits and social performance, Journal of Management Studies 43, 75-91.

Jensen, M. C., 2002, Value Maximization, Stakeholder Theory, and the Corporate Objective Function, Business Ethics Quarterly 12, 235-256.

Kaul, I.P. Conceição, Le Goulven, K. and Mendoza. R.U., 2003, Providing Global Public Goods. Oxford: Oxford University Press.

Kotchen, M.J., 2006, Green markets and private provision of public goods, Journal of Political Economy 114, 816-834.

Lutz S., Lyon T.P., Maxwell J.W., 2000, Quality leadership when regulatory standards are forthcoming, Journal of Industrial Economics 48, 331-48. 
McWilliams, A. and Siegel, D., 2001, Corporate social responsibility: a theory of the firm perspective, Academy of Management Review 26, 117-27.

McWilliams, A. and Wright, P.M., 2006, Corporate Social Responsibility: Strategic Implications, Journal of Management Studies 43, 1-18.

Mitrokostas, E. and Petrakis, E., 2008, Private CSR Activities in Oligopolistic Markets: Is there any room for Regulation?, BE.NE.TeC. Working Paper Series, Working Paper: 2008-16.

Mussa, M. and Rosen, S., 1978, Monopoly and product quality, Journal of Economic Theory $18,301-317$.

Reinhardt, F., 1998, Environmental product differentiation, California Management Review 40, 43-73.

Rode, J.R., Hogarth, M. and Le Menestrel, M., 2008, Ethical differentiation and market behavior: An experimental approach, Journal of Economic Behaviour and Organization 66, 265-280.

Scherer, A. G., and Palazzo, G., 2007, Towards a political conception of corporate responsibility - Business and society seen from a Habermasian perspective, Academy of Management Review 32, 1096-1120.

Shaked, A. and Sutton, J., 1982, Relaxing Price Competition through Product Differentiation, Review of Economic Studies 49, 3-13.

Shaked, A. and Sutton, J., 1983, Natural Oligopolies, Econometrica 51, 1469-83.

Solferino N. and Becchetti L., 2008, La differenziazione etica del prodotto, Economia e Politica Industriale 2008(1), 25-52.

Sundaram, A.K. and A.C. Inkpen, 2004, The Corporate Objective Revisited, Organization Science $15,350-363$.

Toolsema, L., 2009, Interfirm and Intrafirm Switching Costs in a Vertical Differentiation Setting: Green versus Nongreen Products, Journal of Economics and Management Strategy 18, $263-$ 284.

Uchida T., 2007, Information Disclosure Policies: When Do They Bring Environmental Improvements, International Advances in Economics Research 13, 47- 64. 


\section{APPENDIX: TABLES AND FIGURES}

Table 1: Main Characteristics of Treatments in the Market Experiment

\begin{tabular}{|c|c|c|c|c|c|c|}
\hline Treatment & $\begin{array}{l}\text { Energy- } \\
\text { saving } \\
\text { Investment }\end{array}$ & Information & $\begin{array}{l}\text { Contribution } \\
\text { Costs (Net) }\end{array}$ & $\begin{array}{c}\mathbf{N}^{\circ} \text { of } \\
\text { Sessions }\end{array}$ & $\begin{array}{l}\mathbf{N}^{\circ} \text { of } \\
\text { Markets }\end{array}$ & $\begin{array}{l}\mathbf{N}^{0} \text { of } \\
\text { Subjects }\end{array}$ \\
\hline T0 & $\mathrm{NO}$ & $\mathrm{PH}$ & -- & 1 & $1-2$ & 36 \\
\hline T1 & YES & $\mathrm{NH}$ & $\begin{array}{l}\text { Low } \\
\text { (High) }\end{array}$ & 2 & $3-6$ & 72 \\
\hline $\mathbf{T} 2$ & YES & $\mathrm{NH}$ & $\begin{array}{l}\text { High } \\
\text { (Low) }\end{array}$ & 2 & $7-10$ & 72 \\
\hline $\mathbf{T 3}$ & YES & $\mathrm{PH}$ & $\begin{array}{l}\text { High } \\
\text { (Low) }\end{array}$ & 2 & $11-14$ & 72 \\
\hline \multirow[t]{2}{*}{ T4 } & YES & $\mathrm{CH}$ & $\begin{array}{l}\text { High } \\
\text { (Low) }\end{array}$ & 2 & $15-18$ & 72 \\
\hline & & & & TOTAL & 18 & 324 \\
\hline
\end{tabular}

CH: Complete History (selling prices and investment levels). NH: No History. PH: Selling Prices History only. 
Table 2. Design parameters by subsidy scenario for different investment levels T1

(Low investment cost)

\begin{tabular}{|c|c|c|c|c|c|c|}
\hline Scenario & $\begin{array}{l}\text { Invest. } \\
\text { Level }\end{array}$ & Investment & Subsidy & $\begin{array}{l}\text { Energy- } \\
\text { saving }\end{array}$ & Net cost & $\begin{array}{l}\text { Public good } \\
\text { contribution }\end{array}$ \\
\hline \multirow[t]{5}{*}{ S1 } & $\mathbf{0}$ & 0.0 & 0.0 & 0.0 & 0.0 & 0.0 \\
\hline & 1 & 16.1 & 3.6 & 6.3 & 6.2 & 18.9 \\
\hline & 2 & 40.3 & 10.1 & 14.1 & 16.1 & 42.3 \\
\hline & 3 & 80.6 & 32.2 & 30.2 & 18.2 & 90.6 \\
\hline & 4 & 141.0 & 70.5 & 50.4 & 20.1 & 151.2 \\
\hline \multirow[t]{5}{*}{$\mathbf{S 2}$} & $\mathbf{0}$ & 0.0 & 0.0 & 0.0 & 0.0 & 0.0 \\
\hline & 1 & 16.1 & 5.1 & 6.3 & 4.7 & 18.9 \\
\hline & 2 & 40.3 & 14.1 & 14.1 & 12.1 & 42.3 \\
\hline & 3 & 80.6 & 36.7 & 30.2 & 13.7 & 90.6 \\
\hline & 4 & 141.0 & 75.6 & 50.4 & 15 & 151.2 \\
\hline \multirow[t]{5}{*}{ S3 } & $\mathbf{0}$ & 0.0 & 0.0 & 0.0 & 0.0 & 0.0 \\
\hline & 1 & 16.1 & 6.7 & 6.3 & 3.1 & 18.9 \\
\hline & 2 & 40.3 & 18.1 & 14.1 & 8.1 & 42.3 \\
\hline & 3 & 80.6 & 41.3 & 30,2 & 9,1 & 90,6 \\
\hline & 4 & 141 & 80,5 & 50.4 & 10.1 & 151.2 \\
\hline \multirow[t]{5}{*}{ S4 } & $\mathbf{0}$ & 0.0 & 0.0 & 0.0 & 0.0 & 0.0 \\
\hline & 1 & 16.1 & 8.3 & 6.3 & 1.5 & 18.9 \\
\hline & 2 & 40.3 & 22.1 & 14.1 & 4.1 & 42.3 \\
\hline & 3 & 80.6 & 45.8 & 30.2 & 4.6 & 90.6 \\
\hline & 4 & 141 & 85.6 & 50.4 & 5.0 & 151.2 \\
\hline \multirow[t]{5}{*}{ S5 } & $\mathbf{0}$ & 0.0 & 0.0 & 0.0 & 0.0 & 0.0 \\
\hline & 1 & 16.1 & 9.8 & 6.3 & 0.0 & 18.9 \\
\hline & 2 & 40.3 & 26.2 & 14.1 & 0.0 & 42.3 \\
\hline & 3 & 80.6 & 50.4 & 30.2 & 0.0 & 90.6 \\
\hline & 4 & 141.0 & 90.6 & 50.4 & 0.0 & 151.2 \\
\hline
\end{tabular}


Table 3. Design parameters by subsidy scenario for different investment levels T2, T3, T4 (High investment cost)

\begin{tabular}{|c|c|c|c|c|c|c|}
\hline Scenario & $\begin{array}{l}\text { Invest. } \\
\text { Level }\end{array}$ & Investment & Subsidy & $\begin{array}{l}\text { Energy- } \\
\text { saving }\end{array}$ & Net cost & $\begin{array}{l}\text { Public good } \\
\text { contribution }\end{array}$ \\
\hline \multirow[t]{5}{*}{ S1 } & $\mathbf{0}$ & 0.0 & 0.0 & 0.0 & 0.0 & 0.0 \\
\hline & 1 & 24.7 & 5.4 & 9.2 & 10.1 & 27.6 \\
\hline & 2 & 61.9 & 15.5 & 21.7 & 24.7 & 65.1 \\
\hline & 3 & 139.2 & 55.7 & 46.4 & 37.1 & 139.2 \\
\hline & 4 & 247.5 & 123.7 & 77.3 & 46.5 & 231.9 \\
\hline \multirow[t]{5}{*}{$\mathbf{S 2}$} & 0 & 0.0 & 0.0 & 0.0 & 0.0 & 0.0 \\
\hline & 1 & 24.7 & 8.0 & 9.2 & 7.5 & 27.6 \\
\hline & 2 & 61.9 & 21.7 & 21.7 & 18.5 & 65.1 \\
\hline & 3 & 139.2 & 65 & 46.4 & 27.8 & 139.2 \\
\hline & 4 & 247.5 & 135.3 & 77.3 & 34.9 & 231.9 \\
\hline \multirow[t]{5}{*}{$\mathbf{S 3}$} & 0 & $\mathbf{0 . 0}$ & 0.0 & $\mathbf{0 . 0}$ & $\begin{array}{l}0.0 \\
\end{array}$ & 0.0 \\
\hline & 1 & 24.7 & 10.5 & 9.2 & 5 & 27.6 \\
\hline & 2 & 61.9 & 27.8 & 21.7 & 12.4 & 65.1 \\
\hline & 3 & 139.2 & 74.2 & 46.4 & 18.6 & 139.2 \\
\hline & 4 & 247.5 & 147 & 77.3 & 23.2 & 231.9 \\
\hline \multirow[t]{5}{*}{ S4 } & 0 & $\mathbf{0 . 0}$ & 0.0 & 0.0 & 0.0 & 0.0 \\
\hline & 1 & 24.7 & 13 & 9.2 & 2.5 & 27.6 \\
\hline & 2 & 61.9 & 34 & 21.7 & 6.2 & 65.1 \\
\hline & 3 & 139.2 & 83.5 & 46.4 & 9.3 & 139.2 \\
\hline & 4 & 247.5 & 158.5 & 77.3 & 11.7 & 231.9 \\
\hline \multirow[t]{5}{*}{ S5 } & $\mathbf{0}$ & 0.0 & 0.0 & 0.0 & 0.0 & 0.0 \\
\hline & 1 & 24.7 & 15.5 & 9.2 & 0.0 & 27.6 \\
\hline & 2 & 61.9 & 40.2 & 21.7 & 0.0 & 65.1 \\
\hline & 3 & 139.2 & 92.8 & 46.4 & 0.0 & 139.2 \\
\hline & 4 & 247.5 & 170.2 & 77.3 & 0.0 & 231.9 \\
\hline
\end{tabular}


Table 4. Estimation of equation (1)

\begin{tabular}{|c|c|c|c|}
\hline Variable & Coefficient & Std. Error & $p>|t|$ \\
\hline cons. & .0789 & .0136 & .000 \\
\hline $\mathbf{T}$ & .0007 & .0003 & .027 \\
\hline$l p_{i t-1}$ & .3856 & .0471 & .000 \\
\hline$l p_{j t-1}$ & .0656 & .0352 & .065 \\
\hline $\mathrm{C}_{\mathrm{it}}$ Treat $_{1}$ & .0071 & .0024 & .003 \\
\hline $\mathrm{C}_{\mathrm{it}}$ Treat $_{2}$ & .0147 & .0071 & .041 \\
\hline $\mathrm{C}_{\mathrm{it}}$ Treat $_{3}$ & .0146 & .0071 & .042 \\
\hline $\mathrm{C}_{\mathrm{it}}$ Treat $_{4}$ & .0106 & .0042 & .013 \\
\hline $\mathrm{C}_{\mathrm{jt}}$ Treat $_{1}$ & -.0089 & .0046 & .056 \\
\hline $\mathrm{C}_{\mathrm{jt}}$ Treat $_{2}$ & -.0193 & .0087 & .028 \\
\hline $\mathrm{C}_{\mathrm{jt}}$ Treat $_{3}$ & -.0029 & .0051 & .578 \\
\hline $\mathrm{C}_{\mathrm{jt}}$ Treat $_{4}$ & -.0118 & .0062 & .058 \\
\hline$R^{2}=0.3692$ & & $\begin{array}{l}F(11,143) \\
=\quad 31.37\end{array}$ & $\begin{array}{c}\text { Prob > } \\
\text { F=0.000 }\end{array}$ \\
\hline
\end{tabular}


Table 5: Variable List

\begin{tabular}{|l|l|}
\hline Firm demand & $\begin{array}{l}\text { Number of product units sold, ranging from no sales (0) to monopolizing } \\
\text { the market (9) }\end{array}$ \\
\hline Firm price & the firm's own posted price \\
\hline Average price & the mean of others' selling prices per period \\
\hline Firm contribution & the firm's own energy-saving investment \\
\hline $\begin{array}{l}\text { Average } \\
\text { contribution }\end{array}$ & the mean of other firms' average energy-saving investment per period \\
\hline Subsidy & $\begin{array}{l}\text { This variable has 5 possible levels, numbered 0 through 4, so that level 0 } \\
\text { means no contribution, and level } 4 \text { involves maximum contribution to the } \\
\text { public good. }\end{array}$ \\
\hline Saving costs & $\begin{array}{l}\text { This variable has 5 possible levels, numbered } 0 \text { through 4, so that level 0 } \\
\text { means no saving costs, and level } 4 \text { involves maximum saving costs. }\end{array}$ \\
\hline Period & Period/round of the experiment (1 -36 rounds) \\
\hline
\end{tabular}


Table 6: Demand model, equation (2): ordered probit with individual random effects

\begin{tabular}{|c|c|c|c|c|}
\hline & \multicolumn{2}{|c|}{ Model (1) } & \multicolumn{2}{|c|}{ Model (2) } \\
\hline & Estimate & t-value & Estimate & t-value \\
\hline Firm price & -0.045 & $24.95 * * *$ & -0.044 & $24.62 * * *$ \\
\hline Average price & 0.024 & $8.83 * * *$ & 0.024 & $8.70 * * *$ \\
\hline Firm contribution & 0.003 & $3.35 * * *$ & 0.008 & $28.11 * * *$ \\
\hline Average contribution & -0.010 & $16.44 * * *$ & -0.010 & $16.26^{* * *}$ \\
\hline Subsidy when certificate 1 & 0.126 & 0.28 & - & - \\
\hline Subsidy when certificate 2 & 0.012 & 0.08 & - & - \\
\hline Subsidy when certificate 3 & -0.079 & $1.89 *$ & - & - \\
\hline Subsidy when certificate 4 & 0.031 & $2.17 * *$ & - & - \\
\hline Saving costs when certificate 1 & - & - & -2.127 & 0.71 \\
\hline Saving costs when certificate 2 & - & - & 0.583 & 0.47 \\
\hline Saving costs when certificate 3 & - & - & 0.247 & 0.10 \\
\hline Saving costs when certificate 4 & - & - & -0.053 & 0.04 \\
\hline Period & -0.010 & $5.32 * * *$ & -0.012 & $6.34 * * *$ \\
\hline Log likelihood & -5827.02 & & -5826.84 & \\
\hline $\mathrm{N}$ of individuals & 5,305 & & 5,305 & \\
\hline
\end{tabular}

$*, * *, * * *$ indicate significant improvement at 10, 5, 1 percent levels respectively 
Figure 1. Evolution of average posted and selling (clearing) prices by market

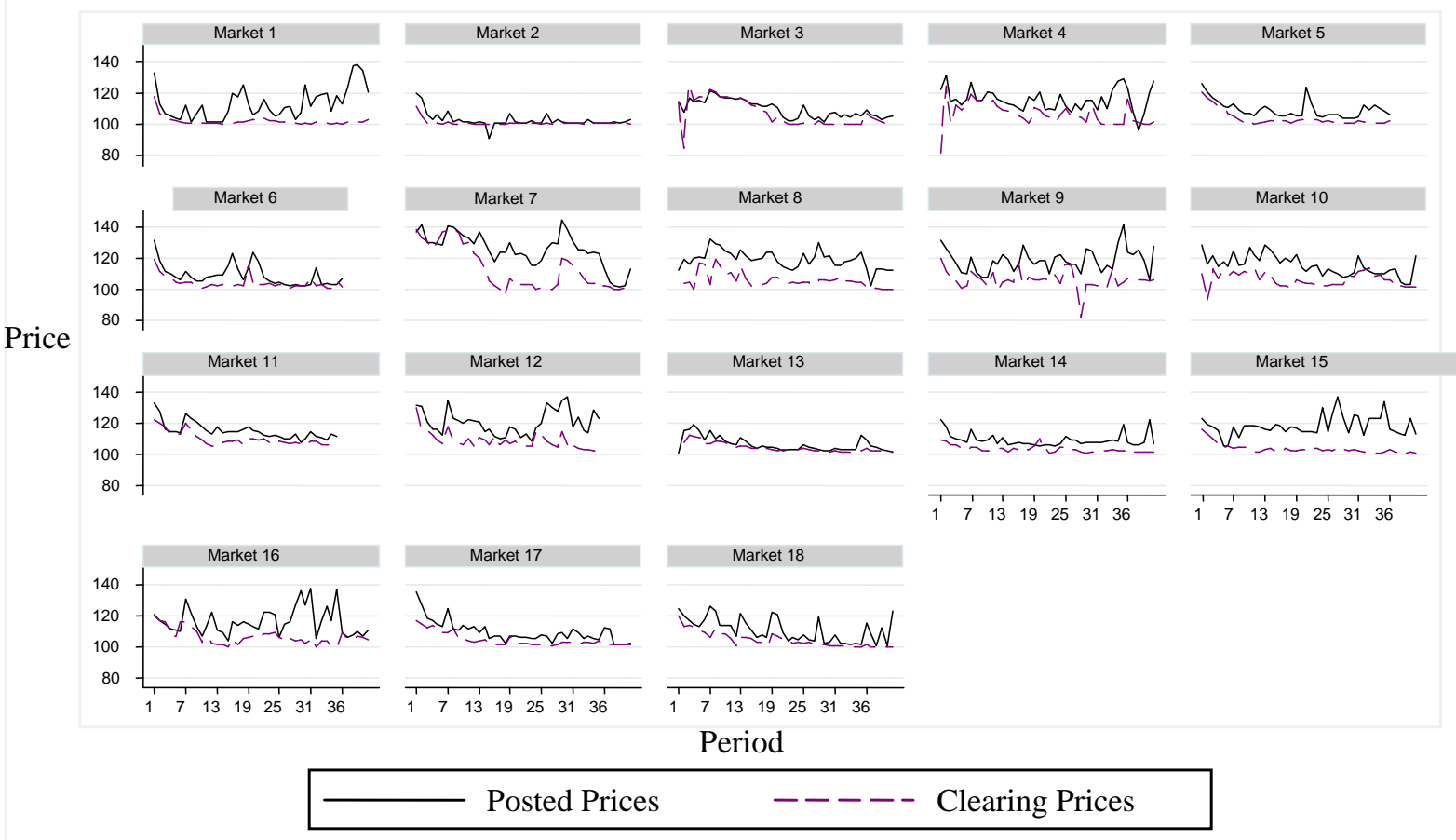

Figure 2. Evolution of average market clearing prices by treatment
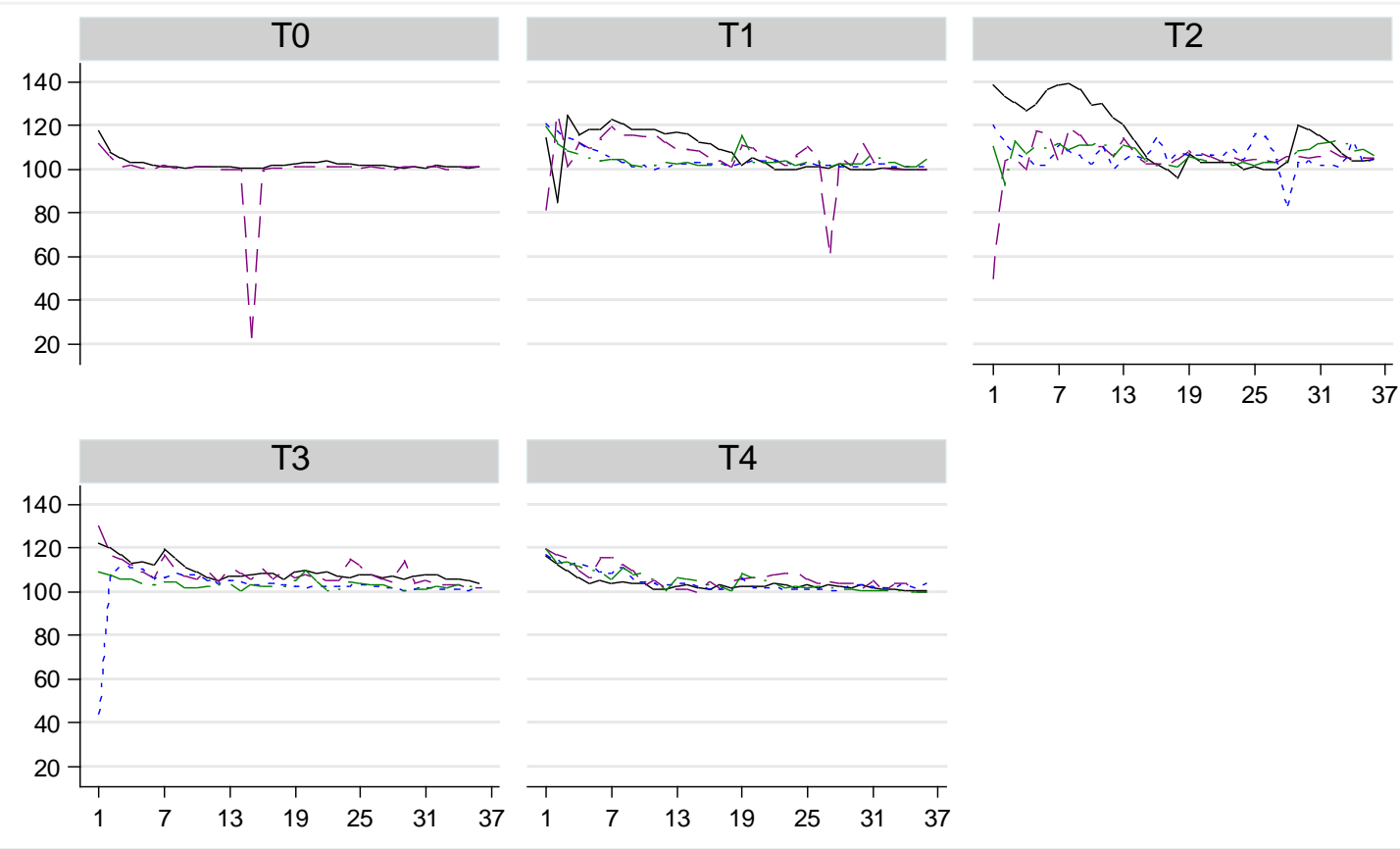

Period

$\begin{array}{cc}\text { Market } 1 & ----- \text { Market } 2 \\ \text { Market } 3 & \text { - _ - - Market } 4\end{array}$ 
Figure 3. Evolution of investments by treatment
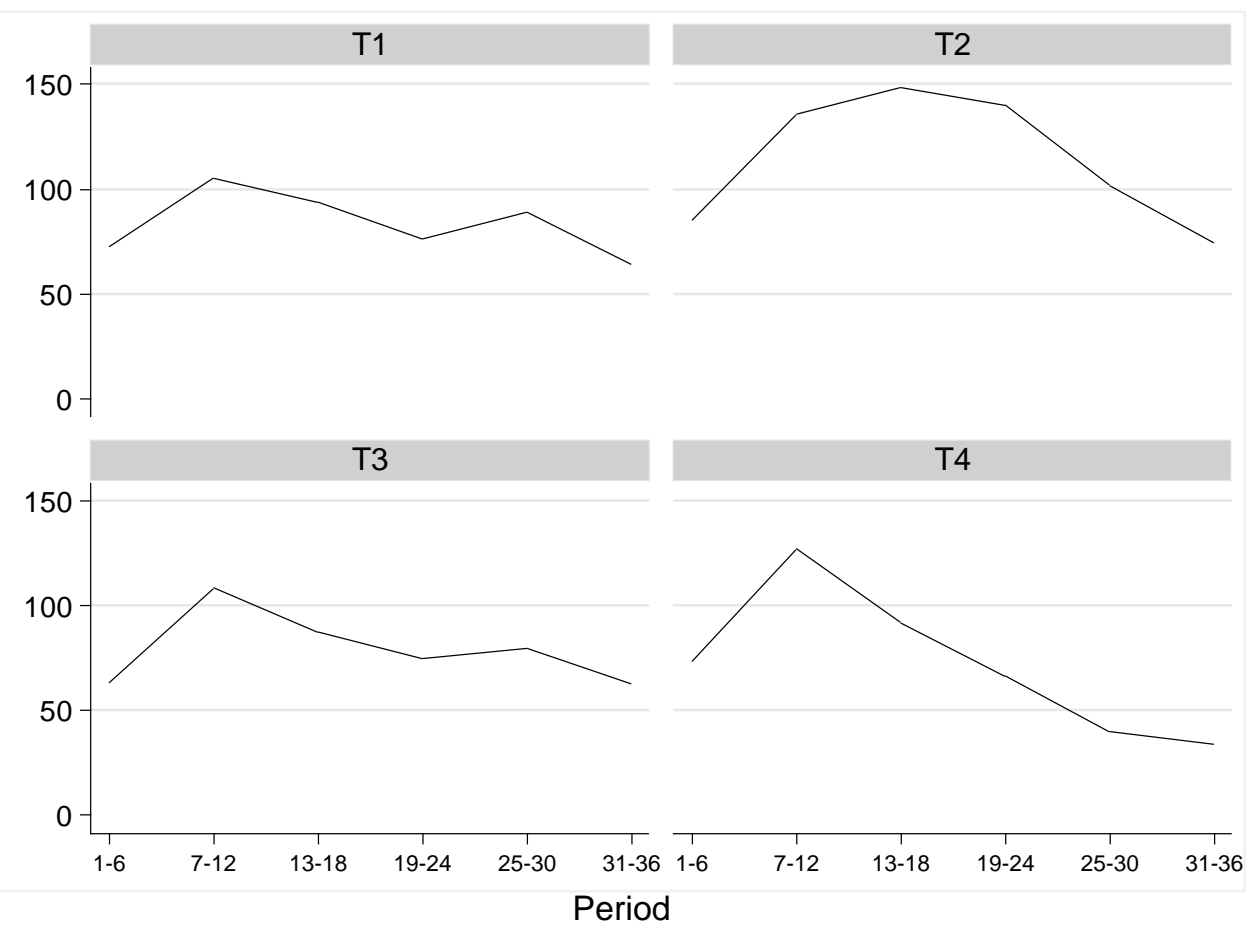

Figure 4: Evolution of average overall and selling firm contribution per market

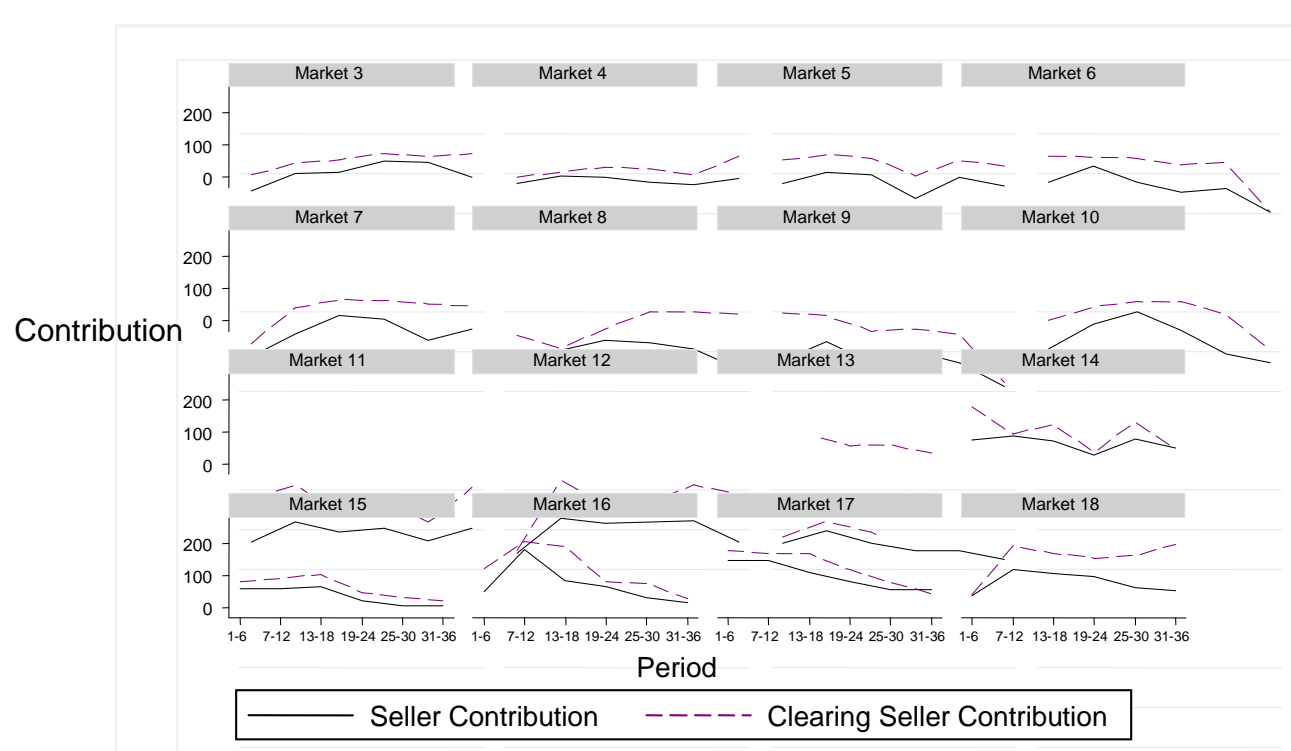


Figure 5. Initial (period 1) posted prices (dots) and purchasing decisions (marked with " $x ")$ per market

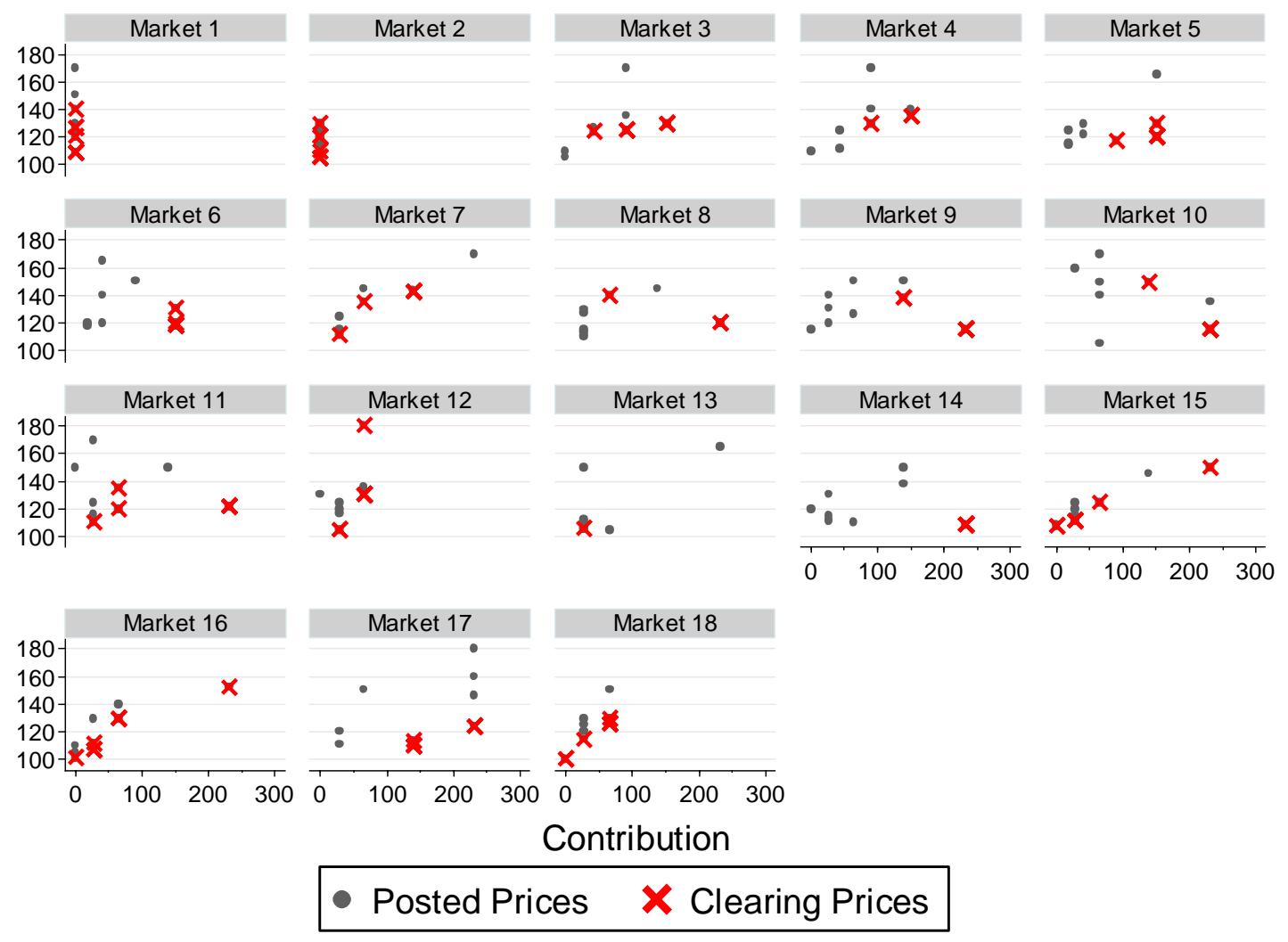


Figure 6. Period 36 posted prices (dots) and purchasing decisions (marked with " $x$ ") per market

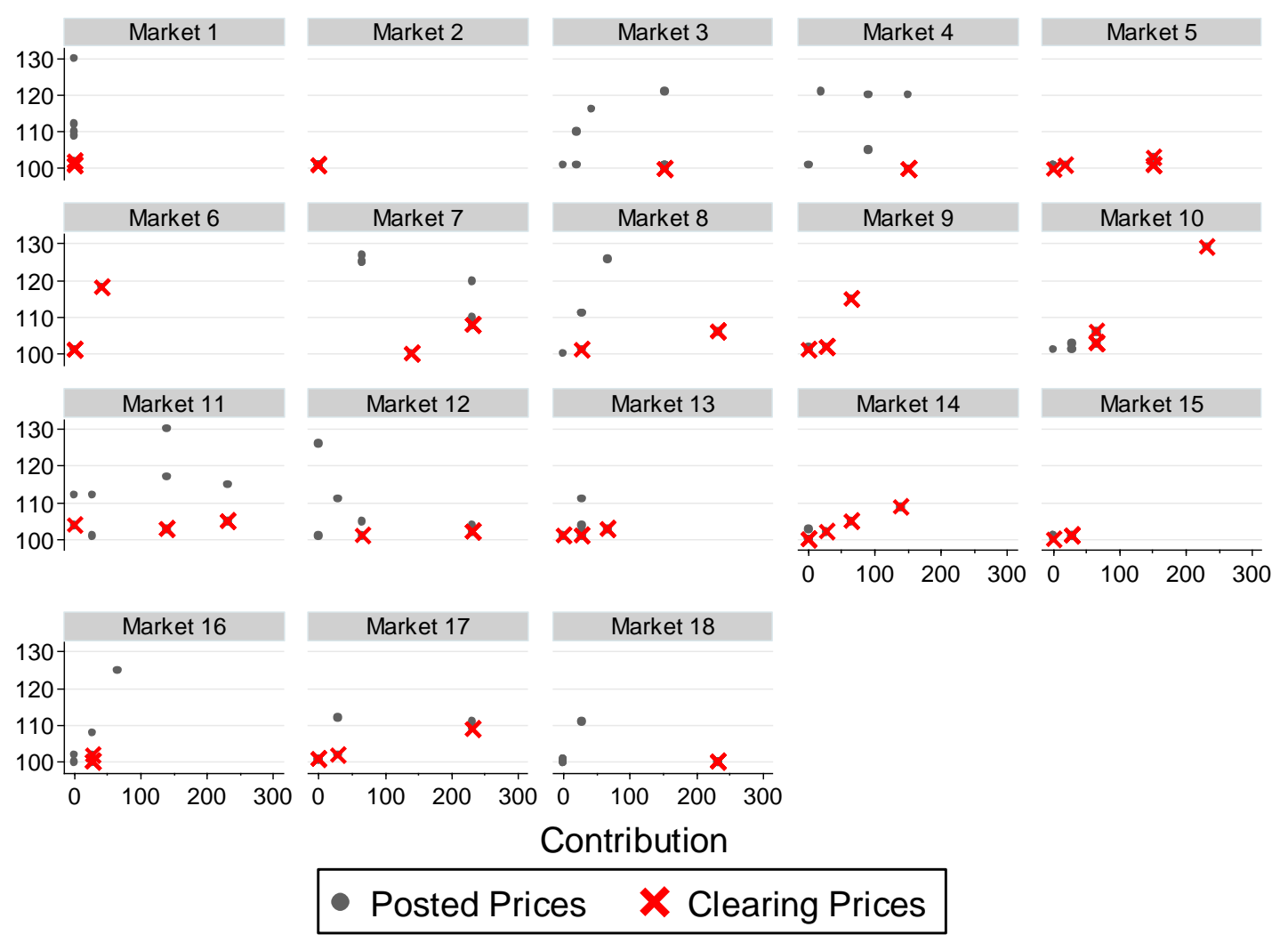


Figure 7. Evolution of average profit by treatment
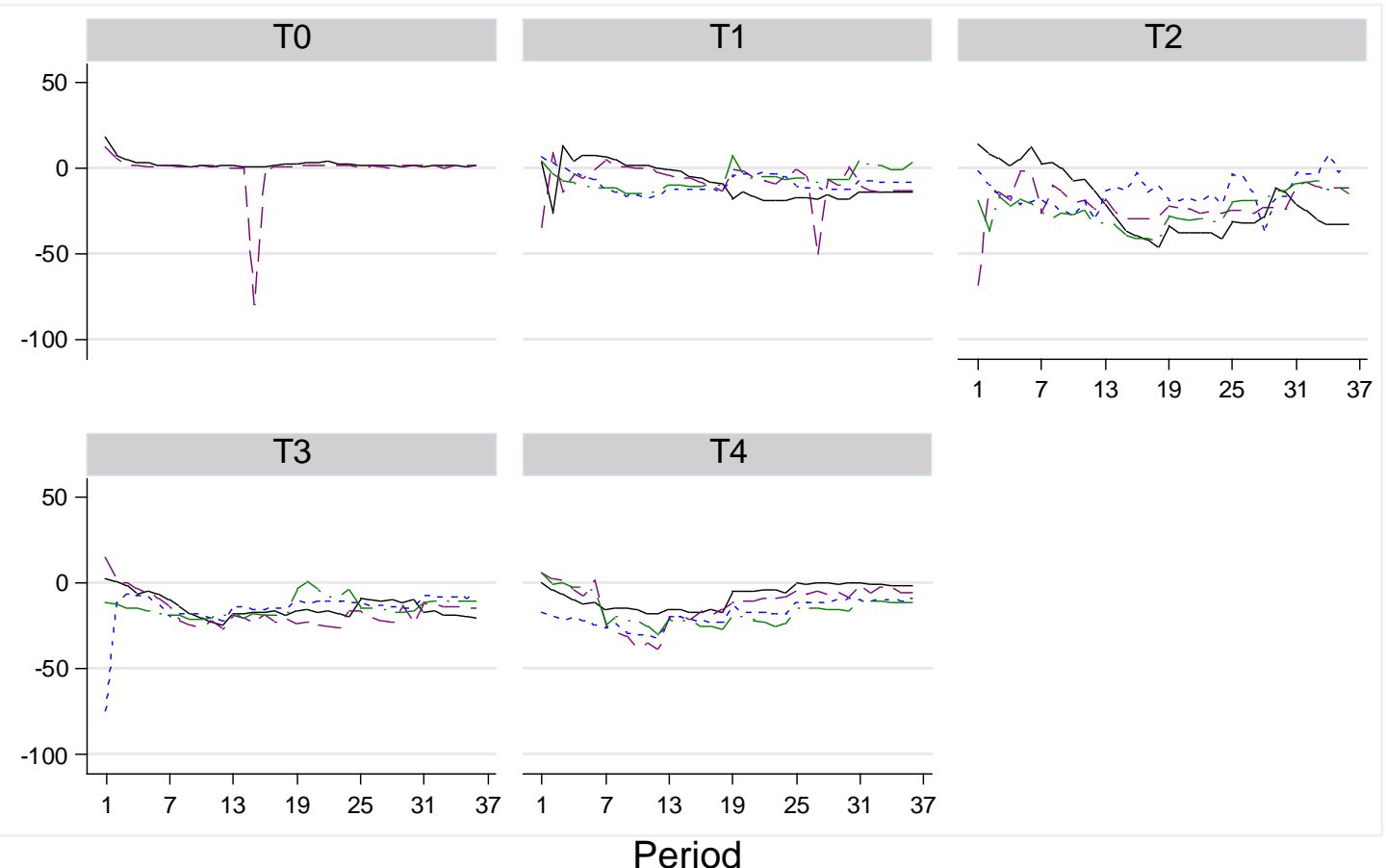

\begin{tabular}{|lll|}
\hline & Market 1 & ---- \\
............ & Market 3 & Market 2 \\
\hline
\end{tabular}

